\title{
Japan hints at a shift to the life sciences
}

Tokyo. Japan's Ministry of Trade and Industry (MITI) and its Science and Technology Agency (STA) are seeking substantial budget increases of 16.9 per cent and 10.7 per cent respectively for 1997 . The new money will be used to help finance ambitious new research projects in the life sciences and to strengthen Japan's basic research infrastructure.

Both agencies, together with other ministries, are backing an ambitious brain research programme, and the STA is also seeking $¥ 1.6$ billion for analysing the structure and function of proteins. These are the first indications of the immediate financial impact of Japan's new five-year plan for science and technology, announced in June.

Under the plan, the government has agreed to increase spending on science and technology by 50 per cent over the next five years, with a total spending target for the period of $¥ 17,000$ billion. The requests will probably be pared down by the Ministry of Finance before the budgets are finalized in December. But, despite deteriorating government finances, the government's public promises mean that large increases for science are anticipated.

Ryutaro Hashimoto, Japan's new prime minister, has been calling on government ministries, which can be very territorial and competitive, to increase their cooperation. $\mathrm{He}$ is reported to have said that collaborative projects will be given high priority, and senior science officials in Tokyo say that this has led ministries to communicate with each other “very well”. MITI wants $¥ 3$ billion for a scheme to collaborate with other ministries in research and development.

The brain research programme is a good example of multiple ministries seeking funds for a multibillion-dollar long-term programme. Various ministries are requesting funding for projects in three major research areas: basic research into the structure and function of the brain; medical research aimed at prevention and treatment of neurological disorders; and research aimed at copying the brain's information-processing functions. The overall brain research plan was sketched out in a document produced by the Science Council of Japan in May (see Nature 381, 266; 1996).

STA has requested $¥ 10$ billion for brain research next year, and $¥ 7.4$ billion to set up a new research institute at the Institute of Physical and Chemical Research (RIKEN), which already has 10 laboratories conducting research related to the brain. Under the plan, the institute will become the focal point of an interministry brain research programme linking national research institutes and universities.

MITI wants $¥ 2.3$ billion for brain research, and plans to set up a new institute - the Brain Function Analysis Experimen- tal Facility - and to develop research at its National Institute of Bioscience and Human Technology in Tsukuba. The ministry is also seeking funding for collaborative research on brain function for advanced information communication systems with the Ministry of Posts and Telecommunications (MPT). The Ministry of Health and Welfare is also asking for $¥ 1.5$ billion for brain research.

Masao Ito, president of the Science Council of Japan, and one of Japan's leading brain researchers, describes the budget proposals as "a very good start". He hopes the proposed institute at RIKEN, of which he is tipped to become the head, will pull together small and large groups of researchers currently dispersed throughout Japan into a well coordinated cohesive research programme. After the ministries get their various projects up and running, he thinks it will be essential to establish a highlevel coordinating committee to manage and direct the overall programme.

In another ambitious project, the STA is asking for almost ten times its 1996 budget for analysing the structure and function of proteins. It has requested $¥ 1.3$ billion to use a beam line at Spring- 8 , the world's largest synchrotron, due to start operations in Nishi Harima, west of Osaka, next year, to analyse protein structures. The agency is also requesting funding for a new initiative to set up a state-of-the-art nuclear magnetic resonance (NMR) centre at RIKEN (see Nature 381, 105; 1996).

The 'NMR Park', which would be open to foreign researchers, could eventually house more than 50 NMRs and will focus on understanding the fundamental structure of proteins. Akiyoshi Wada, former dean of science at Tokyo University, who heads a group of Japanese chemists and biologists backing the project, believes Japan is well placed to develop new techniques and instruments in the field. He hopes that the new initiative will bring together researchers from various disciplines currently in university departments throughout Japan.

Related to these two projects, the STA is asking for $¥ 200$ million for its National Research Institute for Metals. The money will be used to develop new superconducting magnets to develop the world's most powerful $1 \mathrm{GHz}$ NMRs to analyse the structure of of Japan's R\&D 1997 budget requests in $¥$ billion (US\$1 $=¥ 110$ )

1997 Per cent change

$\begin{array}{ll}338.6 & 17 \% \\ 45.6 & 4 \% \\ 1.3 & 8 \% \\ 28.5 & 8 \% \\ 11.3 & 12 \% \\ 24.8 & -3 \% \\ 17.6 & 7 \% \\ 4.9 & 84 \% \\ 2.3 & (\mathrm{New}) \\ 3.0 & (\mathrm{New}) \\ & \end{array}$

$\begin{array}{lc}750.4 & 8 \% \\ 585.8 & 11 \% \\ 183 & 3 \% \\ 324 & 1 \% \\ 93.8 & \\ 3.2 & -10 \% \\ 10 & 28 \% \\ 3.0 & 300 \% \\ 1.8 & 20 \% \\ 1.4 & 764 \% \\ 20.0 & 133 \% \\ 4.1 & 20 \% \\ & 20 \%\end{array}$

